\title{
Conservation implications of prey responses to wild dogs Lycaon pictus during the denning season on wildlife ranches
}

\author{
S. S. Romañach ${ }^{1,2}$ \& P. A. Lindsey ${ }^{1,2}$
}

1 Tropical Resource Ecology Programme, University of Zimbabwe, Harare, Zimbabwe 2 Mammal Research Institute, University of Pretoria, Pretoria, South Africa

Correspondence

Stephanie S. Romañach, Mammal Research Institute, University of Pretoria, Pretoria, 0002, South Africa.

Email: stephanie.romanach@gmail.com

\section{Abstract}

The spread of game ranching in southern Africa provides opportunities for the reestablishment of populations of endangered wild dogs extirpated by livestock ranchers. However, this potential has not been realized, partly because of negative rancher perceptions. Some ranchers believe that wild dogs impart costs by killing wildlife that could be utilized consumptively. Others complain that wild dogs make ungulates 'skittish' and cause local reductions in prey densities while denning. We compared the skittishness and density of prey species inside and outside the denning home ranges of nine wild dog packs in Zimbabwe. Wild dogs had no impact on prey skittishness, but prey species did occur at lower densities inside denning home ranges. In some scenarios, and particularly on fenced game ranches, wild dogs could cause prey population declines during denning. On small game ranches, the use of fences as a tool by wild dogs during hunting can increase the proportion of large prey species in their diet by up to 11 times, and thus increase the minimum area required to support that diet. In addition, game fencing is typically permeable to wild dogs but not their prey, preventing the recovery of prey populations through the natural influx of prey animals into the denning area following departure of the dogs. Wild dogs could thus impose significant financial costs to game ranchers hosting denning packs. Our findings emphasize the importance of promoting the formation of conservancies, where neighbouring landowners remove boundary fences to create larger contiguous wildlife areas. 


\section{Introduction}

Conflict with humans represents one of the primary causes for the decline in the numbers and distribution of many large predator species throughout the world, including African wild dogs Lycaon pictus (Woodroffe \& Ginsberg, 1998; Woodroffe, Thirgood \& Rabinowitz, 2005b). Developing solutions with which to mitigate humanpredator conflict is the most direct way in which conservation of wild dogs and other large carnivores might be achieved. Where predators coexist with livestock, they are often persecuted as a result of attacks on livestock, or pre-emptively in response to the perceived threat to livestock (Romañach, Lindsey \& Woodroffe, 2007; Woodroffe et al., 2007). In some cases, predators are perceived to compete for prey species that could be hunted by paying clients (Thirgood, Woodroffe \& Rabinowitz, 2005); this type of conflict is particularly prevalent in southern Africa (Lindsey, du Toit \& Mills, 2005a).

Game ranches in southern Africa provide unparalleled potential for the expansion of the geographic ranges of wild dogs and other large predators. Legislative changes in Namibia, South Africa and Zimbabwe during recent decades devolved to landowners the right to utilize wildlife and to generate revenue through trophy hunting and the sale of live animals (Bond et al., 2004). These changes resulted in a major shift from livestock ranching to game ranching, which led to significant increases in ungulate populations on private land (van der Waal \& Dekker, 2000; Bond et al., 2004). For example, in South Africa, game ranches comprise an area of $159000 \mathrm{~km}^{2}$, which is close to eight times the area of the country's Kruger National Park (Falkena, 2003); Zimbabwe had $27000 \mathrm{~km}^{2}$ of game ranches by 2000 (before the land reform programme) (Bond et al., 2004); in Namibia 15-25\% of ranches are used for wildlife production (Krug, 2001); and both Botswana and Zambia have expanding game ranching industries [Bond et al., 2004; Barnett \& Patterson, 2006; L. Simwanda (Zambia Environmental Conservation Association), pers. comm.]. There have been some reintroductions of predators on game ranches, but these have been limited primarily to private game reserves used for ecotourism (Hayward et al., 2007). Wild dogs have been reintroduced into 14 reserves, including nine private reserves in South Africa (Gusset et al., 2007), but remain limited in number and distribution on wildlife ranch land (Lindsey, du Toit \& Mills, 2004a).

High values of ungulate species for consumptive utilization (e.g. trophy hunting) have meant that predators are perceived by some ranchers to represent a financial liability and, as a result, are commonly persecuted (Lindsey et al., 2005a). For example, the average trophy fee in South Africa for a sable Hippotragus niger is USD 7700, and USD 980 for a greater kudu Tragelaphus strepsiceros (Patterson \& Khosa, 2005). Persecution is particularly severe for predators such as cheetahs Acinonyx jubatus and wild dogs, which are not generally legally hunted (cheetahs are only hunted in Namibia and Zimbabwe) and so are widely perceived to impose costs on landowners without generating financial returns (Lindsey, Roulet \& Romañach, 2007b). 
Wild dogs are the least popular large carnivores among game ranchers because of their perceived impact on wild ungulate populations (Lindsey et al., 2005a). Some ranchers complain that wild dogs cause a local reduction in the abundance of wild ungulates during the denning season, and that their hunting technique results in an increase in skittishness among prey species (Fanshawe, Frame \& Ginsberg, 1991; Lindsey et al., $2005 a$ ). For most of the year, wild dogs use large home range areas (mean $=545 \mathrm{~km}^{2}$, Creel \& Creel, 2002); however, during the denning period, wild dogs use a restricted range (in South Africa and Zimbabwe, 80 and $125 \mathrm{~km}^{2}$, respectively; Gorman, Mills \& French, 1992; Pole, 1999), which yields greater potential for wild dogs to impact the behaviour or abundance of their prey compared with other times of the year. The denning season in southern Africa coincides with the trophy hunting season and some ranchers complain that the presence of wild dogs makes hunting more difficult by making wildlife more skittish (Lindsey et al., 2005a).

In this study, we tested two beliefs held by wildlife ranchers: wild dogs (1) reduce the abundance of wild ungulates in their home range area during the denning season, and (2) cause wild ungulates to become skittish in their home range during the denning season. A previous study showed that animals were more skittish in a tourist hunting area (Caro, 1999); therefore, we compared our skittishness results with a non-hunting wildlife area. We consider the implications of the presence of wild dogs on small, isolated wildlife ranches; larger ranches and conservancies where neighbouring ranches have removed internal game fencing to create a collaborative wildlife area (adjoining smaller ranches with separating fencing removed); areas with trophy hunting as the primary industry; and areas with ecotourism only.

\section{Methods}

\section{Study sites}

Savé Valley Conservancy ('SVC'; $3442 \mathrm{~km}^{2} ; 20^{\circ} 05^{\prime} \mathrm{S}$ and $32^{\circ} 00^{\prime} \mathrm{E}$ ) is a privately owned wildlife area in south-eastern Zimbabwe. The Laikipia District $\left(9667 \mathrm{~km}^{2} ; 37^{\circ} 02^{\prime} \mathrm{E}\right.$, $0^{\circ} 06^{\prime} \mathrm{N}$ ) in central Kenya is comprised of privately owned commercial ranches that have abundant wildlife mixed with livestock, as well as communally owned land dominated by livestock but also inhabited by wildlife (Romañach et al., 2007). Both study areas are semi-arid with abundant populations of wildlife including all indigenous large carnivores. Wild dogs re-colonized both areas (SVC during the early 1990s, Laikipia during the late 1990s) after having been extinct for 20 years (Pole, 1999; Woodroffe et al., 2005a). In SVC in 2005, the wild dog population was estimated at 120-150 individuals (Pole in litt.), compared with 150 wild dogs in Laikipia (Woodroffe et al., 2005a). Wildlife-based land use in SVC is limited almost entirely to trophy hunting due to the recent collapse in the ecotourism industry in Zimbabwe. For this reason, we selected Laikipia as a comparable area to investigate the effects of denning wild dogs on the skittishness of prey in the absence of trophy hunting. Sport hunting is illegal in Kenya, and photographic tourism was the only form of wildlife use in Laikipia at the time of our fieldwork. 


\section{Data collection}

Data were collected between April and October 2005. We located nine wild dog den sites in SVC (Fig. 1). Wild dogs in Laikipia (located on the equator) have been intensively monitored since 2000 (Woodroffe et al., 2005a), and unlike those in southern Africa, do not have a strict denning season. Wild dogs in several packs have been fitted with radio collars by the research team in Laikipia for easier monitoring through the highly varied terrain used by the wild dogs, which is largely inaccessible by vehicle. Of the dens located, only one was in an area with a network of roads to permit skittishness comparisons with SVC. Wild dogs in SVC were not radio collared, but have been intensively monitored in SVC using trackers since 1996 (Pole, 1999). Using spoor, experienced trackers are able to provide accurate information on animal behaviour through interpretation of events and documentation of the numbers and species of animals involved (Stander, 1998); trackers have been successfully used in several predator studies in southern Africa (Mills, 1990; Bothma \& le Riche, 1993; Stander, 1998).

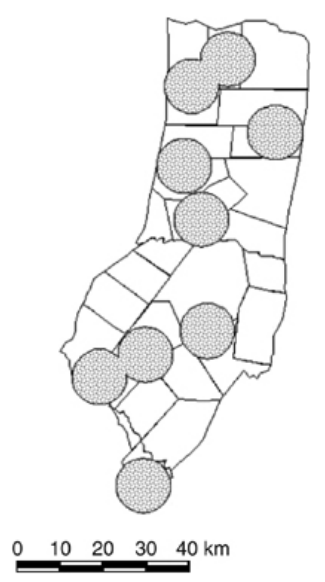

Figure 1 Locations of wild dog dens in Savé Valley Conservancy (SVC) in 2005. Average denning home range area $(6.3 \mathrm{~km}$ radius $)$ is shown as grey circles. Individual ranch boundaries are shown within SVC, but fencing exists only on the perimeter of SVC.To determine skittishness in SVC, we drove a total of $788 \mathrm{~km}$. We drove at $\leq 20 \mathrm{~km} \mathrm{~h}^{-1}$ for $3 \mathrm{~h}$ after sunrise and $2 \mathrm{~h}$ before sunset when the temperatures were cool $\left(15-25^{\circ} \mathrm{C}\right)$ and wildlife was active (Caro, 1999). We simulated a trophy hunting client vehicle by driving with two trackers looking for wildlife, seated on a 'safari seat' fixed to the back of an open vehicle. Although animals are not generally shot from vehicles, they are often located by hunters while driving. We searched for and recorded skittishness of all ungulates we encountered (excluding elephants Loxodonta africana). As soon as an animal was seen, the driver stopped the vehicle (with the engine running and passengers remaining inside) to record the duration until the animal ran away. If the animal did not run after $1 \mathrm{~min}$, it was recorded as not having run. If the animal initially ran or jumped (e.g. because of the sudden stop of the vehicle) but did not leave the site, it was considered not to have run if it stayed within $20 \mathrm{~m}$ of its original position. 
At each animal sighting, we recorded: species, number of animals in the group, numbers of males and females (when discernible), whether the animal ran (yes or no), time until the animal ran, whether the animal was the principal prey of wild dogs (yes or no), distance of the animal from the car when initially seen, distance from the nearest wild dog den (using a handheld Garmin GPS), observer visibility into the bush (m) and dominant woody species. In SVC, the principal prey of wild dogs are impala Aepyceros melampus (73.9\%), greater kudu (20.0\%), common duiker Sylvicapra grimmia $(5.1 \%)$, bushbuck Tragelaphus scriptus (0.9\%) and nyala Tragelaphus angasi $(0.1 \%$; Pole 2000). In Laikipia, the principal prey species of wild dogs are dik dik Madoqua spp. (70.4\%), impala (10.9\%) and, to a lesser extent, hare Lepus saxatilis, klipspringer Oreotragus oreotragus and greater kudu (Woodroffe et al., 2007).

We determined the density of wild ungulates using spoor and dung transects on foot. Only fresh (within the previous week) spoor and dung were recorded. We used transect data to examine the relative densities of wild ungulates 'near' and 'away' from wild dog dens during the denning season, and again 'near' dens after the denning season (to assess any post-denning changes). During denning, wild dogs in SVC use an average home range of $125 \mathrm{~km}^{2}$ (range $35-225 \mathrm{~km}^{2}$ ), which is a $6.3 \mathrm{~km}$ radius from the den (minimum $3.3 \mathrm{~km}$, maximum of $8.5 \mathrm{~km}$ ). Given the logistical difficulty of conducting multiple foot transects over the distance necessary to cover land occurring inside and outside of the denning areas $(>8.5 \mathrm{~km})$, we sampled using 20 transects classified as 'near' dens (within $\leq 3.3 \mathrm{~km}$ ) and 20 'away' from dens ( $\geq 9 \mathrm{~km}$ from a den) for each den site. We followed the transect methods of Woodroffe et al. (2005a), recording spoor and dung along 20 randomly located transects, which were each $50 \mathrm{~m}$ long and $4.75 \mathrm{~m}$ wide. We found little fresh dung, and present the results only from spoor data. Along each transect, we recorded the species producing the spoor and the number of individuals. Spoor appearing in transects were tracked so as not to be counted in other transects.

\section{Statistical analyses}

We used multivariate logistic regression to analyse skittishness (i.e. whether an animal ran) in relation to species, whether the species was a principal prey species of wild dogs, the total number of animals in the group, distance from the car, distance from a wild dog den, visibility and dominant woody species. Model selection was carried out using backward stepwise regression (JMPIN, 2000). Wild ungulate spoor data were tested for normality using the Shapiro-Wilks test (Zar, 1996), and then analysed using standard one-way ANOVA.

Randomizations were used to assess the significance of prey density comparisons in a manner that preserved variance in our measurements. We combined all transects for each den site ( $n=40$ per den), generated the underlying distribution and then randomly assigned each transect to the categories of near and away (during denning), or during and after denning (near dens). For each den site, 1000 randomizations were generated and the results were compared with our field data using a $Z$-test (following the methods of Rossiter et al., 2005). 


\section{Impact on prey populations during the denning season}

We calculated the minimum areas and minimum prey population sizes required to support a wild dog pack of average size (13 individuals; Woodroffe et al., 1997) throughout the year (see Lindsey, du Toit \& Mills, $2004 b$ for a full description of methods). We used prey profiles observed at Kruger National Park (hereafter 'Kruger'; Mills \& Gorman, 1997) and SVC (Pole, 1999). We estimated the number of animals of each prey species killed per year by a pack, the prey population size required to support this offtake and the area required to support the requisite prey population.

To estimate the prey killed during the denning season, we assumed that a pack hunted exclusively in the denning home range [comprising $80 \mathrm{~km}^{2}$ or $15 \%$ of the total annual home range in Kruger (Mills \& Gorman, 1997) and $120 \mathrm{~km}^{2}$ or $24 \%$ in SVC (Pole, 1999)]. We assumed that wild dogs use their entire home range area equally (including the area in which they had denned) for the 9 months when not denning.

\section{Results}

\section{Skittishness}

In SVC, we assessed skittishness at 487 wild ungulate sightings. Of these sightings, 304 were the principal prey of wild dogs. Distance from a wild dog den had no effect on the skittishness of wild ungulates $\left(\chi^{2}=0.66 ; P=0.42\right)$, nor specifically on principal prey species $\left(\chi^{2}=0.01 ; P=0.93\right.$; Fig. 2$)$. Prey species were not more likely to run than nonprey (Fisher's exact one-tailed, $P=0.99$ ); $70 \%$ of non-prey and $58 \%$ of prey species ran from the car. Logistic regression revealed that the only factor that influenced whether animals ran was the total number of animals in the herd (likelihood ratio $\chi^{2}=11.77$; $P<0.01$ ), where the greater the herd size, the more likely the animals were to run.

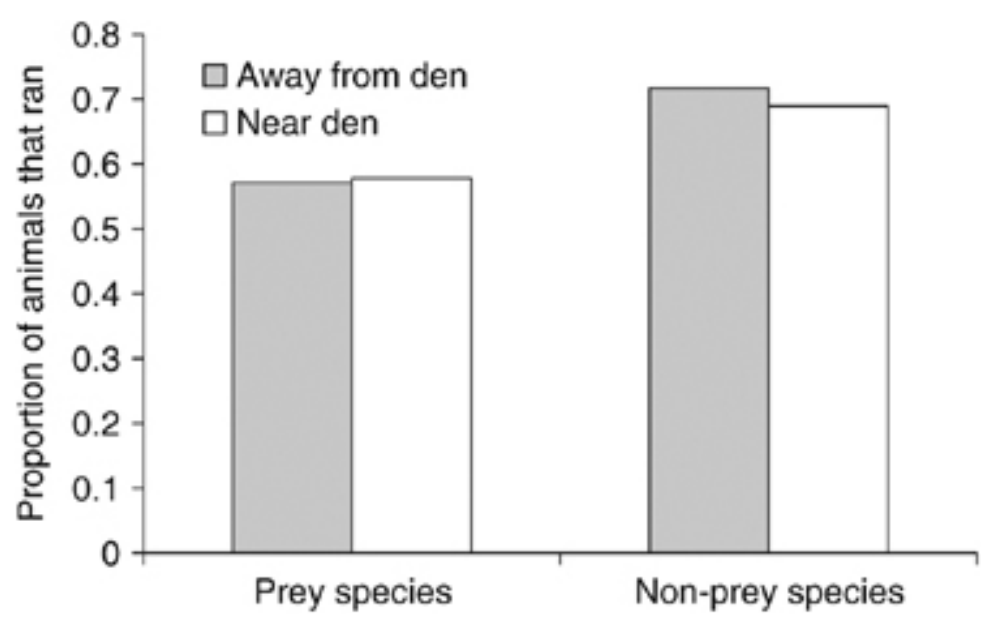

Figure 2 Proportion of 'skittish' animals near wild dog dens $(\leq 3.3 \mathrm{~km}$ from a den) and away from dens ( $\geq 9 \mathrm{~km}$ from a den).At the den site in Laikipia, we recorded skittishness of 39 herds of wild ungulates, 10 of which were primary prey of wild dogs 
in the area. Distance from the wild dog den had no effect on the skittishness of wild ungulates $\left(\chi^{2}=2.37 ; P=0.12\right)$ or specifically on wild dogs' primary prey (only impala seen; $\left.\chi^{2}=1.80 ; P=0.18\right)$. Although we had a small sample of prey species ( $n=10$ herds), we found that prey species were not more likely to run than non-prey (Fisher's exact, one-tailed $P=0.11$ ); $7 \%$ of non-prey and $30 \%$ of prey species ran. In keeping with findings from SVC, the only factor that influenced whether animals ran was the total number of animals in the herd (likelihood ratio $\chi^{2}=10.55 ; P<0.01$ ), where the greater the herd size, the more likely the animals were to run. Ungulates in SVC were more skittish than those in Laikipia $\left(\chi^{2}=35.74 ; P \quad 0.01 ;\right.$ Fig. 3$)$.

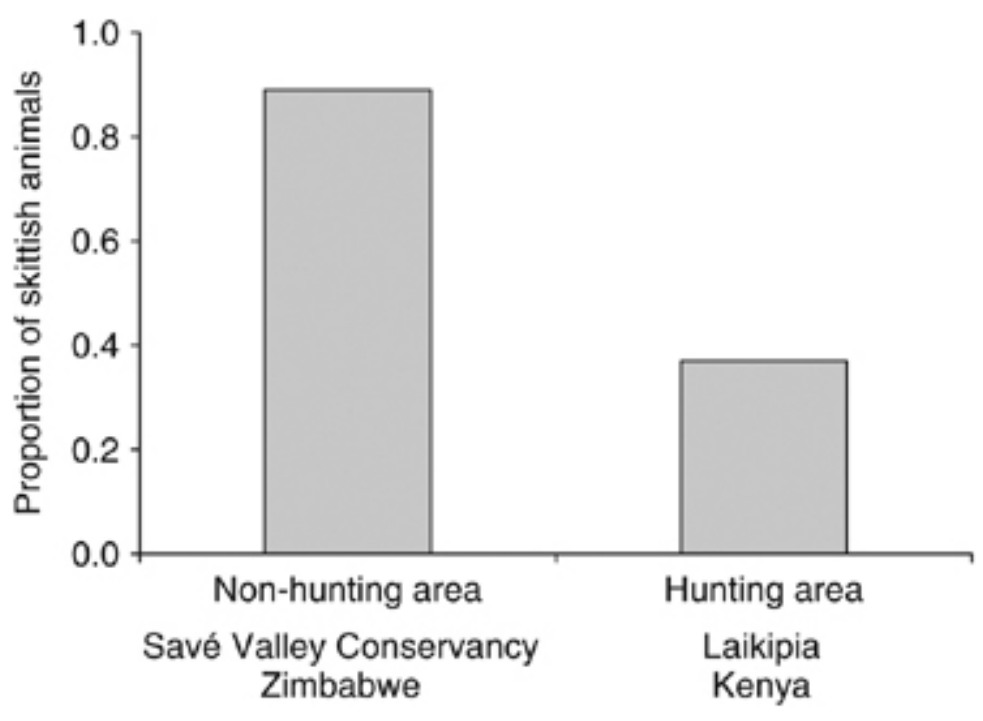

Figure 3 Proportion of 'skittish' animals that ran from the vehicle in a non-hunting area (Laikipia, Kenya) versus a non-hunting area (Save Valley Conservancy, Zimbabwe).

\section{Prey densities}

During the denning season, the densities of all ungulates were lower near wild dog dens compared with away from dens $(F=42.96, P 0.01 ;$ Fig. 4$)$. Prey density varied significantly among packs $(F=21.27, P 0.01)$, and there was an interaction between pack and whether near to a den $(F=7.76, P 0.01)$. Randomizations within packs showed no significant effects for whether prey were near to a den (62/1000 significant runs) or for the interaction (48/1000), showing no confounding effects in the transect data (Fig. 4). 


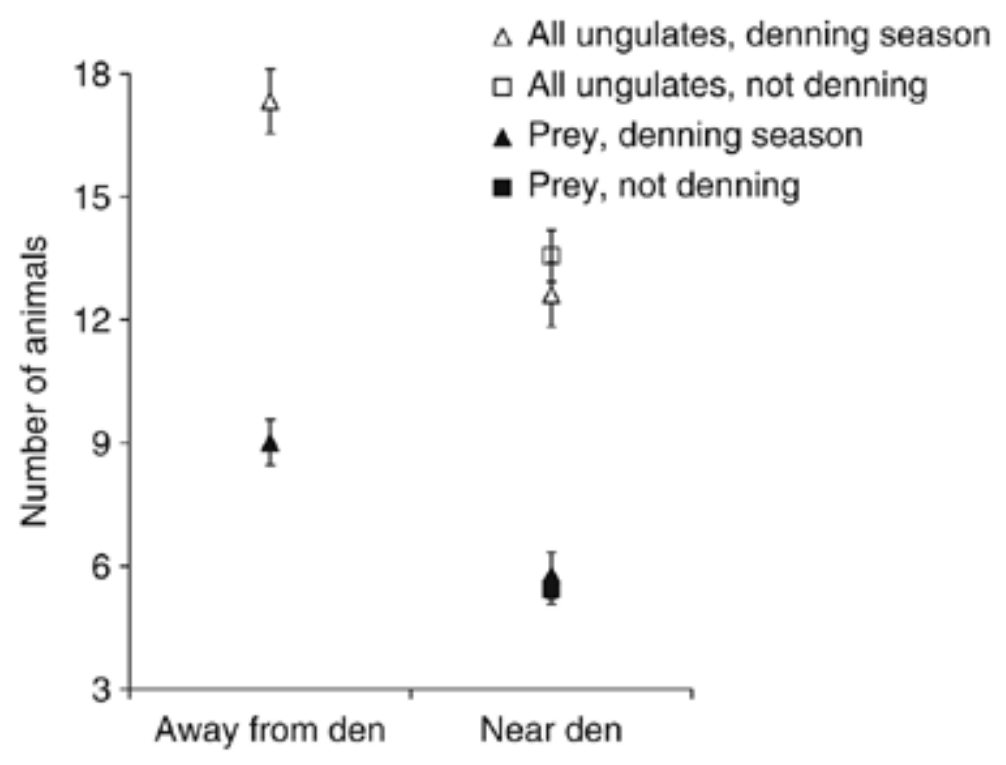

Figure 4 Relative abundances (average \pm se) of prey in transects near wild dog dens during the denning season and after the denning season, and away from dens during the denning season. Open symbols show abundances of all wild ungulates and filled symbols show abundances of prey species only.There was no difference in the density of ungulates or specifically of prey species (near dens) during versus after the denning season (hereafter 'season'; $F=0.43, P=0.51$ ). We found an effect of den site $(F=6.1709$, $P 0.01)$ and a significant interaction between den site and season $(F=8.21, P 0.01)$.

Randomizations (within packs) showed no confounding effects for season $(56 / 1000)$ or the interaction between season and pack (65/1000). We found no effect of habitat on prey densities $(F=0.93, P=0.42)$. We found no relationship between pack size and density of prey during the denning season $(F=0.67, P=0.44)$, or between pack size and change in the density of prey near dens during and after the denning season $(F<0.01$, $P=0.97)$.

\section{Minimum required home range sizes}

The estimated minimum required annual home range areas for an average-sized pack are smaller than the observed home range sizes for wild dogs in Kruger and SVC (Table 1). The minimum home range area required to support predation by wild dogs during the denning period was smaller than the observed wild dog home range areas during the denning season in SVC, but larger than the observed home range in Kruger (Table 1). 
Table 1 Minimum population sizes and area required to support predation by a pack of 13 wild dogs (pack of seven dogs, plus 1 years offspring at 1 year of age), given two prey profiles

\begin{tabular}{|c|c|c|c|c|c|c|}
\hline Ecosystem/species & $\begin{array}{l}\text { No. } \\
\text { of } \\
\text { prey }^{\text {a }}\end{array}$ & $r_{m}^{b}$ & $\begin{array}{l}N_{\text {c }} \\
\text { min }\end{array}$ & $\begin{array}{l}\text { Prey } \\
\text { density }\end{array}$ & $\begin{array}{l}\text { Area } \\
\text { required } \\
\left(\mathbf{k m}^{2}\right)\end{array}$ & $\begin{array}{l}\text { Minimum } \\
\text { required area } \\
\text { as a proportion } \\
\text { of observed } \\
\text { home range }^{d}\end{array}$ \\
\hline \multicolumn{7}{|l|}{ Kruger } \\
\hline \multicolumn{7}{|l|}{ Annual } \\
\hline Impala & 304 & 0.38 & 3200 & 0.08 & 383 & 0.71 \\
\hline Greater kudu & 9 & 0.23 & 157 & 0.008 & 195 & 0.36 \\
\hline \multicolumn{7}{|c|}{ During denning season } \\
\hline Impala & 110 & 0.38 & 1158 & 0.08 & 139 & 1.73 \\
\hline Greater kudu & 3 & 0.23 & 39 & 0.008 & 66 & 0.61 \\
\hline \multicolumn{7}{|c|}{ Savé Valley Conservancy (SVC) } \\
\hline \multicolumn{7}{|l|}{ Annual } \\
\hline Impala & 229 & 0.38 & 2411 & 0.15 & 161 & 0.32 \\
\hline Greater kudu & 40 & 0.23 & 696 & 0.04 & 171 & 0.34 \\
\hline \multicolumn{7}{|c|}{ During denning season } \\
\hline Impala & 93 & 0.38 & 1053 & 0.15 & 70 & 0.56 \\
\hline Greater kudu & 37 & 0.23 & 313 & 0.04 & 77 & 0.61 \\
\hline
\end{tabular}

${ }^{\text {a }}$ Estimated number of prey killed per year by one pack.

${ }^{\mathrm{b}}$ The intrinsic growth rate of the prey population (Caughley \& Krebs, 1983).

${ }^{\mathrm{c}}$ The minimum population size required to support predation by a pack/year.

${ }^{\mathrm{d}}$ Based on annual home range estimates of $537 \mathrm{~km}^{2}$ for Kruger and $499 \mathrm{~km}^{2}$ for SVC, respectively (Mills \& Gorman, 1997; Pole, 1999), and denning season home ranges of 80 and $125 \mathrm{~km}^{2}$ for Kruger and SVC, respectively (Gorman et al., 1992; Pole 1999).

\section{Discussion}

Our results do not support either belief held by ranchers; wild dogs do not cause wild ungulates to become skittish where they hunt, and it appears that they do not reduce the abundance of wild ungulates in their home range area. Wild dogs are compatible with game ranching on large properties; however, there may be some negative effects of wild dogs on smaller, isolated game ranches.

The presence of denning wild dogs had no impact on the skittishness of ungulate species, signifying that wild dogs do not make trophy hunting more difficult. Ungulates 
were less skittish in the non-hunting area in Laikipia compared with SVC, where ungulates are regularly hunted as trophies and for meat. In keeping with this, Caro (1999) found that animals in hunting areas were more skittish than animals in a nonhunting area, and animals hunted for meat were particularly skittish.

There were significantly higher densities of ungulates away from than near wild dog dens. There are three possible explanations for this: (1) wild dog predation causes a reduction in prey densities near dens; (2) the presence of wild dogs causes prey to move out of denning areas; (3) wild dogs select areas with low prey densities. Several factors suggest that explanations (1) or (2) were not the cause of reduced densities near dens. Firstly, the densities of ungulate species that are not the principal prey of wild dogs were also lower near compared with away from dens. Secondly, there was no relationship between pack size and density of prey in the denning home range. Thirdly, the predicted minimum area required to support predation by a pack of wild dogs in SVC was smaller than their observed denning home ranges. Fourthly, there was no increase in prey density near the dens through natural influx of prey following departure of the dogs. There is, however, some evidence to support the third explanation. Wild dogs are likely to select den sites with low prey densities as a mechanism for avoiding lions Panthera leo, which are a major cause of natural wild dog mortality throughout their range (Woodroffe, McNutt \& Mills, 2004). Mills \& Gorman (1997) and Creel \& Creel (2002) showed that wild dogs select habitats with low densities of their preferred prey to avoid contact with lions. Lions are increasing in number in SVC (Davidson \& Romañach, 2007), and during the year before our study, lions were recorded to have killed adult wild dogs and their puppies at a den site.

On large game ranches or in conservancies, if prey populations were reduced by wild dogs in their denning home range areas, this would likely be compensated for to some extent by natural influx of prey following departure of the dogs. However, such an influx may be prevented on smaller, fenced game ranches and so the impacts of wild dogs could be higher under those conditions. In South Africa, most game ranches are smaller than denning home ranges [8.2-49.2 km² (Bothma, 2002; Falkena, 2003), cf. $80-120 \mathrm{~km}^{2}$ ] and are typically surrounded by game fencing, which is generally permeable to wild dogs but not to their prey. Furthermore, in small, fenced areas, wild dogs tend to use fences as a tool to hunt larger species such as waterbuck Kobus ellipsiprymnus and greater kudu (Van Dyk \& Slotow, 2003; Rhodes \& Rhodes, 2004). Large species tend to have slower reproductive rates and occur at lower densities than smaller species, and so the more large species in the prey profile, the larger the required home range (Lindsey et al., 2004b). Larger species such as greater kudu also tend to be more valuable as hunting trophies than smaller species such as impala (Lindsey et al., $2005 b$ ). As a result, wild dogs denning on small, fenced game ranches might be expected to cause reductions in prey populations and thus impart financial costs to landowners. Game ranches in other countries in southern Africa are generally larger than those in South Africa. However, Fig. 1 highlights that while most ranches within SVC are relatively large $\left(70-125 \mathrm{~km}^{2}\right)$, they are still generally smaller than the average home range of wild dogs. Therefore, even in areas where individual ranches are relatively large, the retention of fencing between adjacent properties may increase the 
financial impacts of wild dogs during denning.

Promoting the formation of conservancies should be a key thrust of wild dog conservation efforts. In addition to enabling the natural influx of prey into denning areas after the denning season, and reducing the likelihood of wild dogs using fences to kill large prey, larger areas can be of suitable size to support the full spectrum of indigenous mammal fauna including the largest species. Charismatic species such as elephants, rhinos Diceros bicornis/Ceratotherium simum and lions make ecotourism a more viable land use on conservancies than on small game ranches (Falkena, 2003). Large carnivores including wild dogs are key draw cards for eco-tourists (Lindsey et al., $2007 a$ ). There is a significant willingness among tourists to pay to view wild dogs, and the potential financial gains are sufficient to offset the costs associated with their predation under most circumstances (Lindsey et al., 2005b). Previous work has shown that ranchers whose primary land use is ecotourism and those whose properties form part of conservancies are more positive towards predators than those on smaller, fenced ranches (Lindsey et al., 2005a). One means to encourage the formation of conservancies (and promote ecotourism as a land use) could be through the introduction of tax incentives for ranchers who remove fencing separating their land from that of their neighbours.

Wild dogs are an emotive species and so negative attitudes may take time to change, even in light of potential financial benefits for ranchers and falsehood of traditional prejudices about the extent of negative effects on prey populations. Evidence from the United States and Europe suggests that while public attitudes towards wolves Canis lupus have improved gradually over the last few decades, the attitudes of hunters and ranchers have been slower to improve (Williams, Ericsson \& Heberlein, 2002; Ericsson $\&$ Heberlein, 2003). Awareness programmes highlighting the potential economic and ecological benefits associated with wild dogs may hasten attitude change towards Africa's second most endangered carnivore. Likewise, encouraging conditions conducive to large carnivore conservation, such as promoting the formation of conservancies, may be crucial for the persistence of predator populations. If tolerance towards wild dogs and other predators on wildlife ranching land can be increased, these areas could potentially support populations of global significance.

\section{References}

Barnett, R. \& Patterson, C. (2006). Sport hunting in the southern African development community region: an overview. TRAFFIC East/southern Africa report, Johannesburg, South Africa.

Bond, I., Child, B., de la Harpe, D., Jones, B., Barnes, J. \& Anderson, H. (2004).

Private land contribution to conservation in South Africa. In Parks in transition: 29-62. 
Child, B. (Ed). London: Earthscan Publications Ltd.

Bothma, J. \& le Riche, E.A.N. (1993). Disturbance bias when tracking Kalahari leopards Panthera pardus by spoor. Koedoe 36, 109-112.

Bothma, J.P. (2002). Some economics of game ranching. In Proceedings of a symposium on game ranch planning and management: 23-40. Onderstepoort, South Africa.

Caro, T. (1999). Demography and behaviour of African mammals subject to exploitation. Biol. Conserv. 91, 91-97.

Caughley, G. \& Krebs, C. (1983). Are big animals simply little mammals writ large? Oecologia 59, 7-17.

Creel, S. \& Creel, N.M. (2002). The African wild dog: behaviour, ecology and conservation. Princeton: Princeton University Press.

Davidson, Z. \& Romañach, S.S. 2007. Estimations of lion and hyena density in the Savé Valley Conservancy using two different census techniques: spoor transects and call-up stations. Unpublished report for Savé Valley Conservancy Technical Advisory Committee.

Ericsson, G. \& Heberlein, T.A. (2003). Attitudes of hunters, locals, and the general public in Sweden now that the wolves are back. Biol. Conserv. 111, 149-159.

Falkena, H. (2003). Game ranch profitability in South Africa. The SA Financial Sector Forum, Rivonia.

Fanshawe, J.H., Frame, L.H. \& Ginsberg, J.R. (1991). The wild dog - Africa's vanishing carnivore. Oryx 25, 137-146. 
Gorman, M.L., Mills, M.G.L. \& French, J. (1992). Satellite tracking of the African wild dog Lycaon pictus. In Wildlife telemetry: remote monitoring and tracking of animals: 219-228 Priede, I.G. \& Swift, S.M. (Eds). London: Ellis Horwood.

Gusset, M., Ryan, S., Hofmeyr, M., Van Dyk, G., Davies-Mostert, H., Graf, J., Owen, C., Szykman, M., Macdonald, D., Monfort, S., Wildt, D., Maddock, A., Mills, M., Slotow, R. \& Somers, M. (2007). Efforts going to the dogs? Evaluating attempts to reintroduce endangered wild dogs in South Africa. J. Appl. Ecol.

Hayward, M., Adendorff, J., O'Brien, J., Sholto-Douglas, A., Bissett, Lucius, C., Moolman, C., Bean, P., Fogarty, A., Howarth, A., Slater, R. \& Kerley, G. (2007). The reintroduction of large carnivores to the Eastern Cape, South Africa: an assessment. Oryx 41, 1-9.

JMPIN (2000). JMPIN version 4.0.2. Cary, NC, USA: SAS Institute Inc.

Krug, W. (2001). Private supply of protected land in southern Africa: a review of markets, approaches, barriers and issues. Workshop paper World Bank/OECD International Workshop on Market Creation for Biodiversity Products and Services, Paris, 25 and 26 January 2001.

Lindsey, P.A., Alexander, R., Mills, M.G.L., Romañach, S.S. \& Woodroffe, R. (2007a). Wildlife viewing preferences of visitors to protected areas in South Africa: implications for the role of ecotourism in conservation. J. Ecotourism. 6, 19-33.

Lindsey, P.A., du Toit, J.T. \& Mills, M.G.L. (2004a). The distribution and population status of African wild dogs Lycaon pictus outside protected areas in South Africa. S. Afr. J. Wildl. Res. 34, 143-151.

Lindsey, P.A., du Toit, J.T. \& Mills, M.G.L. (2004b). Area and prey requirements of 
wild dogs Lycaon pictus under varying habitat conditions: implications for reintroductions. S. Afr. J. Wildl. Res. 34, 77-86.

Lindsey, P.A., du Toit, J.T. \& Mills, M.G. (2005a). Attitudes of ranchers towards African wild dogs Lycaon pictus: conservation implications for wild dogs on private land. Biol. Conserv. 125, 113-121.

Lindsey, P.A, du Toit, J.T., Mills, M.G. \& Alexander, R. (2005b). The potential contribution of ecotourism to wild dog Lycaon pictus conservation. Biol. Conserv. 123, 339-348.

Lindsey, P.A., Roulet, P.A \& Romañach, S.S. (2007b). Economic and conservation significance of the trophy hunting industry in sub-Saharan Africa. Biol. Conserv. 134, $455-469$.

Mills, M.G.L. (1990). Kalahari Hyaenas: the comparative behavioural ecology of two species. London: Allen \& Unwin.

Mills, M.G.L. \& Gorman, M.L. (1997). Factors affecting the density and distribution of wild dogs in the Kruger National Park. Conserv. Biol. 11, 1397-1406.

Patterson, C. \& Khosa, P. (2005). Background research paper: a status quo study on the professional and recreational hunting industry in South Africa. http://www.wag.co.za/Canned\%20lion/final_draft.html.

Pole, A.J. (1999). The behaviour and ecology of African wild dogs, Lycaon pictus in an environment with reduced competitor density. $\mathrm{PhD}$ thesis, University of Aberdeen.

Rhodes, R. \& Rhodes, G. (2004). Prey selection and use of natural and man-made barriers by African wild dogs while hunting. S. Afr. J. Wildl. Res. 34, 135-142. 
Romañach, S.S., Lindsey, P.A. \& Woodroffe, R. (2007). Determinants of attitudes toward predators in central Kenya and suggestions for increasing tolerance in a livestock-dominated landscape. Oryx 41, 185-195.

Rossiter, S.J, Ransome, R.D., Faulkes, C.G., Le Comber, S.C. \& Jones, G. (2005). Mate fidelity and intra-lineage polygyny in greater horseshoe bats. Nature 437, 408-411.

Stander, P.E. (1998). Spoor counts as indices of large carnivore populations: the relationship between spoor frequency, sampling error and true density. J. Appl. Ecol. $35,378-385$.

Thirgood, S., Woodroffe, R. \& Rabinowitz, A. (2005). The impact of human-wildlife conflict on human lives and livelihoods. In People and wildlife: conflict or coexistence?: 13-26. Woodroffe, R., Thirgood, S. \& Rabinowitz, A. (Eds). Cambridge: Cambridge University Press.

Van der Waal, C. \& Dekker, B. (2000). Game ranching in the Northern Province of South Africa. S. Afr. J. Wildl. Res. 30, 151-156.

Van Dyk, G. \& Slotow, R. (2003). The effects of fences and lions on the ecology of African wild dogs reintroduced to Pilanesberg National Park, South Africa. Afr. Zool. 38, 79-94.

Williams, C.K., Ericsson, G. \& Heberlein, T.A. (2002). A quantitative summary of attitudes toward wolves and their reintroduction (1972-2000). Wildl. Soc. Bull. 30, $575-584$.

Woodroffe, R., Ginsberg, J. \& Macdonald, D. (1997). The African Wild Dog-Status Survey and Conservation Action Plan: 166. IUCN, Gland, Switzerland.

Woodroffe, R. \& Ginsberg, J.R. (1998). Edge effects and the extinction of populations 
inside protected areas. Science 280, 2126-2128.

Woodroffe, R., Lindsey, P.A., Romañach, S.S. \& ole Ranah, S.M.K. (2007). African wild dogs (Lycaon pictus) can subsist on small prey: implications for conservation. J. Mammal. 88, 181-193.

Woodroffe, R., Lindsey, P.A., Romañach, S.S., Stein, A. \& ole Ranah, S.M.K. (2005a). Livestock predation by endangered African wild dogs Lycaon pictus in northern Kenya. Biol. Conserv. 124, 225-234.

Woodroffe, R., McNutt, J.W. \& Mills, M.G.L. (2004). African wild dog Lycaon pictus. In Canids: foxes, wolves, jackals and dogs, IUCN status survey and conservation action plan: 174-183. Sillero-Zubiri, C., Hoffmann, M. \& Macdonald, D.W. (Eds). Cambridge: IUCN Publication.

Woodroffe, R., Thirgood, S. \& Rabinowitz, A. (2005b). The impact of human-wildlife conflict on natural ecosystems. In People and wildlife: conflict or coexistence?: 21-32. Woodroffe, R., Thirgood, S. \& Rabinowitz, A. (Eds). Cambridge: Cambridge University Press.

Zar, J.H. (1996). Biostatistical analysis. 3rd edn. London: Prentice-Hall. 